Canadian

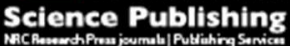

Biochemistry and Cell Biology Biochimie et biologie cellulaire

\title{
Advances in lactoferrin research concerning bovine mastitis
}

\begin{tabular}{|r|l|}
\hline Journal: & Biochemistry and Cell Biology \\
\hline Manuscript ID & bcb-2016-0044.R4 \\
\hline Manuscript Type: & Mini Review \\
\hline Date Submitted by the Author: & 01-Nov-2016 \\
\hline Complete List of Authors: & $\begin{array}{l}\text { Shimazaki, Kei-ichi; Fuji Woman's University } \\
\text { Kawai, Kazuhiro; Azabu University, School of Veterinary Medicine }\end{array}$ \\
\hline Keyword: & $\begin{array}{l}\text { lactoferrin, antimicrobial activity, bovine milk, mastitis treatment, mastitis } \\
\text { prevention }\end{array}$ \\
\hline \multicolumn{2}{|l}{} \\
\hline
\end{tabular}


Advances in lactoferrin research concerning bovine mastitis

Kei-ichi Shimazaki (corresponding author)

Fuji Woman's University, Sapporo, 001-0016, JAPAN

shimazaki_k@frontier.hokudai.ac.jp

Kazuhiro Kawai

School of Veterinary Medicine, Azabu University, Sagamihara, 252-5201, JAPAN

kawai@azabu-u.ac.jp 


\begin{abstract}
Lactoferrin is a multi-functional, iron-binding glycoprotein found in milk and other exocrine secretions. Lactoferrin in milk plays vital roles in the healthy development of newborn mammals and is also an innate resistance factor involved in the prevention of mammary gland infection by microorganisms. Inflammation of the udder due to bacterial infection is referred to as mastitis. There have been many investigations into the relationships between lactoferrin and mastitis, which fall into several categories. The main categories are fluctuations in the lactoferrin concentration of milk, lactoferrin activities against mastitis pathogens, elucidation of the processes underlying the onset of mastitis, participation of lactoferrin in the immune system, and utilization of lactoferrin in mastitis treatment and prevention. This review article describes lactoferrin research concerning bovine mastitis. In the 1970s, many researchers reported that the lactoferrin concentration fluctuates in milk from cows with mastitis. From the late 1980s, many studies clarified the infection-defense mechanism in the udder and the contribution of lactoferrin to the immune system. After 2000, the processes underlying the onset of mastitis were elucidated in vivo and in vitro, and lactoferrin was applied for the treatment and prevention of mastitis.
\end{abstract}

Keywords: lactoferrin, mastitis treatment, mastitis prevention, bovine milk, antimicrobial activity 


\section{Introduction}

Lactoferrin is an iron-binding glycoprotein that belongs to the transferrin family of proteins. The first biological function of lactoferrin reported was its bacteriostatic activity (Reiter and Oram, 1967). Since then, many biological functions of lactoferrin have been found, and it is now recognized as a multifunctional protein. A fundamental role of lactoferrin in exocrine secretions is to behave as an innate defense factor, and lactoferrin secreted in milk plays vital roles for both mother and neonate. Lactoferrin in milk promotes the healthy growth of newborn babies and calves by assisting in the formation of enterobacteria flora and the activation of mucosal immunity and systemic immunity (Baldi et al., 2005; Prgomet et al., 2007; Sherman, 2010). Lactoferrin also helps to prevent infections of the mother's mammary glands, mainly during non-lactating periods (Smith and Schanbacher, 1977). Bacterial invasion into the udder induces inflammation of mammary tissues, which is known as mastitis (Schalm et al., 1971; Bradley, 2002; De Vliegher et al., 2012). Clinical mastitis presents physiological abnormalities in the udder such as swelling, heat, redness, hardness, or pain. Bacterial infection without any visible signs or clinical appearance is called subclinical mastitis.

Mastitis of dairy cows decreases milk productivity both quantitatively and qualitatively, resulting in huge economic losses. Eradication of mastitis in dairy cows is a long-standing goal that has not yet been achieved. Mastitis cows are commonly treated with antibiotics; however, antibiotic-contaminated milk causes serious problems when the milk is shipped for processing. Antibiotic-contaminated milk inhibits the growth of lactic acid bacteria, which are necessary for the production of cheese, yogurt, and other fermented milk products. Moreover, antibiotics in milk affect human intestinal bacterial flora and may also promote the emergence of antibiotic resistant bacteria (Gomes and Henriques, 2016). Therefore, many studies on the role of lactoferrin in mastitis have been performed, including trials for the prevention and treatment of mastitis. Due to serious concerns about drug resistance in microorganisms, the World Health Organization recently began its "Global action plan on antimicrobial resistance" (World Health Organization, 2015), underscoring the need to reduce the overuse of antibiotics. The present review article focuses on the defensive function of bovine lactoferrin against bovine mastitis.

\section{Outline of research progress}

The early reports about the relationship between lactoferrin and mastitis appeared in the 1970s. In these early studies, it was reported that the lactoferrin concentration in milk changes at each stage of lactation. In the colostrum, lactoferrin concentration is very high and gradually decreases. During the non-lactating period, which is known as the dry period, involution of mammary tissue has occurred and highly concentrated lactoferrin is detected in the mammary gland and teat cistern. An increase of lactoferrin concentration in mastitis milk was also reported. In the 1980s to 1990s, many studies clarified the defense mechanisms 
against udder infection, including the action of the complement system in infected mammary tissues, the mechanism of the outbreak of inflammation, the behavior of immune cells, the effects of lactoferrin on the immune system, the control of the production of several cytokines, the inactivation of bacterial endotoxin and lipopolysaccharides (LPS). After 2000, the processes underlying the onset of mastitis were elucidated in vitro and in vivo. Areas of study have included the increase of infection during the perinatal period, the fluctuation of quantitative patterns of lymphocytes and cytokines in milk, and the dynamic behavior of lactoferrin after intramammary administration. Reports on the use of lactoferrin for the treatment of mastitis have been published, such as those studying the combined use of lactoferrin and antibiotics against bacterial infection. The infusion of lactoferrin or its hydrolysate into the mammary gland through the teat canal has also been attempted, and has yielded good results and is getting closer to practical use.

\section{Fluctuations in lactoferrin concentrations of milk}

Fluctuations in lactoferrin concentrations in milk during lactation were observed as far back as the 1970s. Under normal conditions, the lactoferrin concentration of colostral milk is up to about $2 \mathrm{mg} / \mathrm{ml}$ and decreases gradually to baseline levels during lactation period ( 0.02 to $0.5 \mathrm{mg} / \mathrm{ml}$ ) (Harmon et al., 1975, 1976; Smith and Schanbacher, 1977; Suzuki et al., 1977; Gaunt et al., 1980). Almost all concentration measurements of lactoferrin have been performed with milk defatted or skimmed milk from dairy cattle using immunological methods such as electroimmunodiffusion, single radial immunodiffusion (SRID) or enzyme-linked immunosorbent assay (ELISA). Interestingly, lactoferrin concentrations in colostrums of Japanese beef cattle are lower than those of Holstein-Friesian or Jersey cattle (Tsuji et al., 1990; Ishikawa et al., 1992).

During the lactating period, milk flow rinses bacteria that have entered the mammary cistern and teat cistern, but no rinse effect can be expected during non-lactating periods. At these stages, the frontline defense against bacterial invasion is the formation of a keratin plug at the teat canal (Comalli et al., 1984). The second-line of defense is a system containing phagocytic cells and antibacterial materials that inactivate invading bacteria. Such antibacterial proteins and peptides are secreted in milk, and they function effectively and cooperatively with lactoferrin as described in the next section.

From the early stages of studies, it was noticed that lactoferrin concentration increased in mastitis milk (Harmon et al., 1975, 1976). In acute mastitis milk, the lactoferrin content is more than that of pre-acute mastitis milk (Kawai et al., 1999). It is generally known that lactoferrin in milk is secreted from mammary epithelial cells (Hurley and Rejman, 1993; Huang et al., 2012). Moreover, the increase of lactoferrin concentration in mastitis milk is evidenced by increases in its mRNA expression in mammary tissues with experimentally induced mastitis (Schmitz et al., 2004) and also by proteomic analysis (Boehmer et al., 2010). Polymorphonuclear leukocytes (PMN) contain lactoferrin and other antibiotic proteins but no 
lactoferrin was detectable in bovine eosinophils, lymphocytes or monocytes (Levy, 1996). As PMNs infiltrate into mammary gland tissue during inflammation, the contribution of PMNs for lactoferrin in whey was estimated with endotoxin infused cows (Harmon and Newbould, 1980). From their experiments, it was suggested that PMNs were not the major source of lactoferrin in milk during mastitis because on average of $4.9 \%$ of the peak lactoferrin levels in whey could have come from the PMNs.

\section{Antimicrobial activities of lactoferrin against mastitis pathogens}

It is well known that lactoferrin shows not only bacteriostatic activity but also bactericidal and antifungal activities (Orsi, 2004; Jenssen and Hancock, 2009; Yen et al., 2011). The bacteriostatic activity is due to iron ion chelation by apo-lactoferrin (Reiter and Oram, 1967; Arnold et al., 1980), but lactoferrin shows several ways to suppress bacterial growth. For example, strong binding ability with LPS (Ellison et al., 1988), occluding porins on the surface of bacteria (Sallmann et al., 1999), inhibition of bacterial biofilm formation (Singh et al., 2002; Gomes et al., 2016), and cooperation with lysozyme (Suzuki et al., 1989; Ellison and Giehl, 1991) or with immunoglobulin A (IgA) (Watanabe et al., 1984).

Antibacterial activities of lactoferrin against mastitis pathogens have been reported since the late 1970s. The main mastitis-causing microorganisms are listed in Table 1. The more important pathogens include coagulase-negative staphylococci (CNS), Staphylococcus aureus, Streptococcus, coliform bacteria, and others (De Vliegher et al., 2012) and shown in Table 1. It has been observed that bacteria isolated from mastitis milk show different sensitivity or resistance against lactoferrin and lactoferrin hydrolysates produced by pepsin and lactoperoxidase as shown in Table 2. Milk contains not only lactoferrin but other antibacterial substances such as lactoperoxidase, immunoglobulins, lysozyme, $\beta$-defensin, etc. (Thompson-Crispi et al., 2014) that inactivate bacteria, prevent bacterial adherence to mammary tissue surfaces, and neutralize toxins. Antibodies (also referred to as immunoglobulins) are transferred from blood and secreted into the milk by the mammary glands. Lactoperoxidase produces a bactericidal substance, hypothiocyanite ion (OSCN') (Aune and Thomas, 1977), and lysozyme is a bacteriolysis enzyme. $\beta$-Defesin is a cationic peptide that induces membrane depolarization and cell lysis (Ganz, 2003; Meade et al., 2014), and it has been reported that its mRNA is induced in mammary tissue by mastitis (Swanson et al., 2004). These findings indicate the formation of an effective defense system by different anti-infective milk proteins and peptides with different mechanisms.

5. Participation of lactoferrin in the innate defense system in the mammary gland

The anti-infective function of lactoferrin is caused by its direct behavior against microorganisms as described above and also by its immunomodulatory activities (Targowski, 1983; Hanson, 2007; Griesbeck-Zilch et al., 2009; Legrand, 2012). There have been observed certain physiological changes at the inflammation sites of infected mammary tissue (Schalm 
et al., 1971; Harmon, 1994; De Vliegher et al., 2012) : for example, changes in blood vessel permeability, permeation of blood proteins (serum albumin, immunoglobulin, etc.) into milk, migration of phagocytes and white blood cells (leukocytes), and decreases in the synthesis of milk components (caseins, lactose, and milk fats). The number of cells, mainly leukocytes in milk, is called the somatic cell count (SCC) and is used as an indicator of mammary abnormality (Harmon, 1994). SCC and lactoferrin concentrations in milk are markedly decreased after antibiotic treatment of clinical mastitis (Kawai et al., 2014), but the relationship between them has not been completely resolved. Many studies of immune responses in mammary glands with mastitis have also been performed (McDougall et al., 2009; Kushibiki, 2011; De Vliegher et al., 2012; Chaneton et al., 2013), but they are too complex to summarize in this short review.

Cytokines concerned with inflammatory responses include tumor necrosis factor- $\alpha$ (TNF- $\alpha$ ) and interleukins (IL) such as IL-1, IL-2, and IL-6 (Cray et al., 2009). Lactoferrin inhibition of their production from monocytes and PMN has been reported (Crouch et al., 1992; Machnicki et al., 1993; Mattsby-Baltzer et al., 1996; Kushibiki, 2011). On the other hands, it is reported that bovine and human lactoferrin and lactoferricin stimulated IL-8 release from human PMN (Shinoda et al., 1996). Observations in vitro show that lactoferrin does not inhibit the biological activities of TNF- $\alpha$, IL-1, IL-2, or IL-6, but instead inhibits the activation of leukocytes and prevents the production of cytokines from leukocytes at inflamed tissues (Mattsby-Baltzer et al., 1996; Conneely, 2001). When the inhibitory activities of bovine lactoferrin, human lactoferrin, and lactoferricin B on LPS-induced IL-6 released from monocytes (THP-1) were compared, suppressive effects on cytokine release were observed with bovine lactoferrin and lactoferricin B (Mattsby-Baltzer et al., 1996). Other lactoferrin effects on immune defenses have been reported such as the activation of the complement system through an alternative pathway, the increase of phagocytic cells in milk, and the promotion of phagocytosis (Kai et al., 2002a, 2002b).

It is well known that LPS induces inflammation at tissues invaded by bacteria. After bacterial LPS binds to Toll-like receptor 4 (TLR4) of host cells, the production of inflammatory cytokines through certain signaling pathways occurs. However, there have been many reports on lactoferrin inhibitory effects of inflammatory responses to mastitis (Machnicki et al., 1993; Mattsby-Baltzer et al., 1996; Conneely, 2001; Kushibiki et al., 2008, 2009). It has been suggested that such activities may be due to the ability of lactoferrin to inhibit the binding of LPS to CD14 receptors on macrophages (Conneely, 2001). Moreover, it is known that the lactoferrin-LPS complex shows opposing effects: immune suppression (e.g. competition with lactoferrin binding protein and CD14) and immune activation (e.g. induction of TLR4 signaling by lactoferrin or the lactoferrin-LPS complex) (Puddu et al., 2010; Latorre et al., 2012). In general, it is considered that lactoferrin neutralizes the effects of LPS because of its strong LPS-binding ability (Kutila et al., 2004; Kushibiki et al., 2008; Drago-Serrano et al., 2012). It is interesting that lactoferrin orally administered to calves reduces metabolic and 
hormonal disturbances during LPS-induced inflammation (Kushibiki et al., 2008, 2009). On the other hand, in vitro experiments using E. coli have shown that LPS does not affect the antibacterial activity of lactoferrin, while lactoferricin B loses its activity in the presence of high concentrations of LPS (Murata et al., 2009).

\section{Mastitis treatment with lactoferrin}

With the processes underlying the onset of mastitis having been elucidated in vitro and in vivo, applications of lactoferrin for the treatment and prevention of bovine mastitis have appeared. The report on the disposition kinetics of lactoferrin after intramammary administration showed that the mean elimination half-life was 2.2 hours with a maximum mean concentration being reached between 1 and 4 hours (Kutila et al., 2002). Comparative studies of lactoferrin injection into mammary glands with experimentally induced mastitis showed that the number of bacteria, SCC, and daily milk yield did not differ significantly, but LPS concentrations in milk compared with bacterial count were significantly lower in lactoferrin-treated cows than in the antibiotics treatment group (Kutila et al., 2004). The experimental conditions and the results of lactoferrin intramammary administration are shown in Table 3.

Some researchers considered that intact lactoferrin alone lacks sufficient antibacterial activity, and other approaches to increase the impact of its effects have been performed. One is the use of a combination of lactoferrin and antibiotics. There are several studies combining the use of lactoferrin and antibiotics to treat mastitis, such as for chronic mastitis caused by $\beta$-lactam resistant $S$. aureus (Petitclerc et al., 2007). Combination therapy enhances the bacteriological cure rates (Lacasse et al., 2008). It is assumed that lactoferrin binds to the bacterial membrane through LPS, making it easier for the antibiotics to enter and destroy bacterial cells. It has also been observed that lactoferrin in combination with penicillin $\mathrm{G}$ enhances $S$. aureus susceptibility to phagocytosis (Diarra et al., 2003). In addition, decreases of RNA expression of TNF- $\alpha$ with lactoferrin-antibiotic combination treatment have been reported (Komine et al., 2006). Moreover, it has been reported that lactoferrin reduces the $\beta$-lactamase activity of $S$. aureus due to repression of transcription of the enzyme (Lacasse et al., 2008). Examples of the use of lactoferrin-antibiotic combinations are shown in Table 4.

Another treatment of mastitis utilizes injection of lactoferrin hydrolysates into the quarters of cows (the udder comprises four independent glands known as quarters) with subclinical mastitis (Kawai et al., 2003). Lactoferrin hydrolysates were prepared by pepsin digestion and contain every fragment, including certain functional peptides such as lactoferricin B, a strong antibactericidal peptide. This attempt has shown good therapeutic results such as the decrease of bacterial count in the milk from infected quarters and the number of quarters with bacteria was significantly decreased (Table 3 ).

\section{Mastitis prevention with lactoferrin}


A high infection ratio has been observed when lactoferrin content is low in the milk of non-lactating cows (Farke et al., 2008). Therefore, the selection and breeding of cows with lactoferrin-rich milk has been attempted (Arnould et al., 2009). Another approach is the production of pathogen-resistant cows by selection or by genetic engineering (Wall et al., 2005; Donovan et al., 2005; Huang et al., 2015)). Such ideas have come from comparative studies of mastitis resistance and lactoferrin gene polymorphisms or single nucleotide polymorphisms (SNPs). Vaccination using killed or inactivated pathogens is another possibility for mastitis prevention, but vaccination only reduces the severity of the clinical symptoms and does not prevent new infections (Bradley, 2002; McDougall et al., 2009; Morimoto et al., 2011). Thus, it must be concluded that the breeding of resistant cows and vaccination trials are not yet practical.

The importance of the non-lactating period in the epidemiology of intramammary infection has been recognized, namely in that new infection ratios are observed to be the highest just before and after drying off (cessation of milking to allow the dairy cow to stop lactating) (Bradley and Green, 2004). This phenomenon may be due to deficiencies of the mammary gland defense system. During non-lactating periods, the teat canal is blocked off by a keratin plug (Krömker and Friedrich, 2009), and antimicrobial substances including lactoferrin are present in mammary glands. However, this defense system is insufficient at the beginning of drying and winds down at the end of the non-lactating period. Accordingly, lactoferrin intramammary injection during non-lactating periods has been performed and has shown profound protective effects against bacterial infection (Itagaki and Tanaka, 2015) as in Table 3.

\section{Conclusion and prospects}

Bovine mastitis is a long-standing problem that has not yet been solved. Antibiotic treatment is the main therapeutic approach to mastitis. However, the high risk of milk contaminated with antibiotics causes many problems, and new treatment and preventative approaches are strongly desired. Developments such as vaccines against mastitis pathogens and the breeding of mastitis-resistant cows are still in the early phase of development and have not yet succeeded. As a matter of course, hygiene management is essential to prevent clinical and subclinical mastitis. Because consumers desire milk to be absolutely safe, newer and safer antibacterial preparations are greatly needed. Concomitant use of lactoferrin and antibiotics may be advantageous for curing mastitis by decreasing the amount of antibiotics. The use of lactoferrin against mastitis currently makes a great deal of sense because it is a natural anti-infective milk protein. The use of bovine lactoferrin for cattle health is natural and very effective as both a preventative agent of mastitis and a therapeutic agent after infection when used together with appropriate methods recommended by the regional instruction organization such as the National Mastitis Council (Middleton et al., 2014). Based on trends in research of lactoferrin and mastitis, we can expect substantial improvements in its 
application.

\section{Acknowledgements}

We would like to thank to Masahiro Inoue. Without his suggestions and comments, this paper would not have materialized.

\section{References}

Arnold, R.R., Brewer, M., and Gauthier, J.J. 1980. Bactericidal activity of human lactoferrin: sensitivity of a variety of microorganisms. Infect. Immun. 28(3), 893-898.

Arnould, V.M.-R., Soyeurt, H., Gengler, N., Colinet, F.G., Georges, M. V, Bertozzi, C., Portetelle, D., and Renaville, R. 2009. Genetic analysis of lactoferrin content in bovine milk. J. Dairy Sci. 92(5), 2151-2158. doi: 10.3168/jds.2008-1255.

Aune, T.M., and Thomas, E.L. 1977. Accumulation of hypothiocyanite ion during peroxidase-catalyzed oxidation of thiocyanate Ion. Eur. J. Biochem. 80(1), 209-214. doi: 10.1111/j.1432-1033.1977.tb11873.x.

Baldi, A., Ioannis, P., Chiara, P., Eleonora, F., Roubini, C., and Vittorio, D. 2005. Biological effects of milk proteins and their peptides with emphasis on those related to the gastrointestinal ecosystem. J. Dairy Res. 72(Special issue), 66-72.

Becker, K., Heilmann, C., and Peters, G. 2014. Coagulase-negative staphylococci. Clin. Microbiol. Rev. 27(4), 870-926. doi: 10.1128/CMR.00109-13.

Boehmer, J.L., Ward, J.L., Peters, R.R., Shefcheck, K.J., McFarland, M.A., and Bannerman, D.D. 2010. Proteomic analysis of the temporal expression of bovine milk proteins during coliform mastitis and label-free relative quantification. J. Dairy Sci. 93(2), 593-603. doi: 10.3168/jds.2009-2526.

Bradley, A.J. 2002. Bovine mastitis: an evolving disease. Vet. J. 164(2), 116-128.

Bradley, A.J., and Green, M.J. 2004. The importance of the nonlactating period in the epidemiology of intramammary infection and strategies for prevention. Vet. Clin. North Am. Food Anim. Pract. 20(3), 547-568. doi: 10.1016/j.cvfa.2004.06.010.

Chaneton, L., Bontá, M., Pol, M., Tirante, L., and Bussmann, L.E. 2013. Milk lactoferrin in heifers: Influence of health status and stage of lactation. J. Dairy Sci. 96(8), 4977-4982. doi: $10.3168 /$ jds.2012-6028

Conneely, O.M. 2001. Antiinflammatory activities of lactoferrin. J. Am. Coll. Nutr. 20(5 suppl), 389S-397S.

Comalli, M.P., Eberhart, R.J., Griel, L.C., and Rothenbacher, H. 1984. Changes in the microscopic anatomy of the bovine teat canal during mammary involution. Am. J. Vet. Res. 45(11), 2236-2242.

Cray, C., Zaias, J., and Altman, N.H. 2009. Acute phase response in animals: a review. Comp. Med. 59(6), 517-526. Available from https://www.ncbi.nlm.nih.gov/pmc/articles/PMC2798837/ [accessed 19 January 2017]. 
Crouch, S.P., Slater, K.J., and Fletcher, J. 1992. Regulation of cytokine release from mononuclear cells by the iron-binding protein lactoferrin. Blood 80(1), 235-240.

De Vliegher, S., Fox, L.K., Piepers, S., McDougall, S., and Barkema, H.W. 2012. Invited review: Mastitis in dairy heifers: nature of the disease, potential impact, prevention, and control. J. Dairy Sci. 95(3), 1025-1040. doi: 10.3168/jds.2010-4074.

Diarra, M.S., Petitclerc, D., Deschênes, E., Lessard, N., Grondin, G., Talbot, B.G., and Lacasse, P. 2003. Lactoferrin against Staphylococcus aureus mastitis. Lactoferrin alone or in combination with penicillin $\mathrm{G}$ on bovine polymorphonuclear function and mammary epithelial cells colonisation by Staphylococcus aureus. Vet. Immunol. Immunopathol. 95(1-2), 33-42. doi: 10.1016/S0165-2427(03)00098-9.

Donovan, D.M., Kerr, D.E., and Wall, R.J. 2005. Engineering disease resistant cattle. Transgenic Res. 14(5), 563-567. doi: 10.1007/s11248-005-0670-8.

Drago-Serrano, M.E., de la Garza-Amaya, M., Luna, J.S., and Campos-Rodríguez, R. 2012. Lactoferrin-lipopolysaccharide (LPS) binding as key to antibacterial and antiendotoxic effects. Int. Immunopharmacol. 12(1), 1-9. doi: 10.1016/j.intimp.2011.11.002.

Ellison, R.T., and Giehl, T.J. 1991. Killing of gram-negative bacteria by lactoferrin and lysozyme. J. Clin. Invest. 88(4), 1080-1091. doi: 10.1172/JCI115407.

Ellison, R.T., Giehl, T.J., and LaForce, F.M. 1988. Damage of the outer membrane of enteric gram-negative bacteria by lactoferrin and transferrin. Infect. Immun. 56(11), 2774-2781.

Farke, C., Meyer, H.H.D., Bruckmaier, R.M., and Albrecht, C. 2008. Differential expression of $\mathrm{ABC}$ transporters and their regulatory genes during lactation and dry period in bovine mammary tissue. J. Dairy Res. 75(4), 406-414. doi: 10.1017/S002202990800335X.

Ganz, T. 2003. Defensins: antimicrobial peptides of innate immunity. Nature Rev. Immunol. 3(9), 710-720. doi: 10.1038/nri1180.

Gaunt, S.N., Raffio, N., Kingsbury, E.T., Damon, R.A., Johnson, W.H., and Mitchell, B.A. 1980. Variation of lactoferrin and mastitis and their heritabilities. J. Dairy Sci. 63(11), 1874-1880. doi: 10.3168/jds.S0022-0302(80)83154-7.

Gomes, F., and Henriques, M. 2016. Control of bovine mastitis: Old and recent approaches. Curr. Microbiol. 72(4) 377-382. doi: 10.1007/s00284-015-0958-8.

Gomes, F., Saavedra, M.J., and Henriques, M. 2016. Bovine mastitis disease/pathogenicity: evidence of the potential role of microbial biofilms. Pathog. Dis. 74(3). ftw 006, doi: http://dx.doi.org/10.1093/femspd/ftw006.

Griesbeck-Zilch, B., Osman, M., Kühn, C., Schwerin, M., Bruckmaier, R.H., Pfaffl, M.W., Hammerle-Fickinger, A., Meyer, H.H.D., and Wellnitz, O. 2009. Analysis of key molecules of the innate immune system in mammary epithelial cells isolated from marker-assisted and conventionally selected cattle. J. Dairy Sci. 92(9), 4621-4633. doi: 10.3168/jds.2008-1954.

Hanson, L.A. 2007. Session 1: Feeding and infant development breast-feeding and immune function. Proc. Nutr. Soc. 66(3), 384-396. doi: 10.1017/S0029665107005654. 
Harmon, R.J. 1994. Physiology of mastitis and factors affecting somatic cell counts. J. Dairy Sci. 77(7), 2103-2112. doi: 10.3168/jds.S0022-0302(94)77153-8.

Harmon, R.J., and Newbould, F.H.S. 1980. Neutrophil leukocyte as a source of lactoferrin in bovine milk. Am. J. Vet. Res. 41(10), 1603-1606.

Harmon, R.J., Schanbacher, F.L., Ferguson, L.C., and Smith, K.L. 1976. Changes in lactoferrin, immunoglobulin $\mathrm{G}$, bovine serum albumin, and $\alpha$-lactalbumin during acute experimental and natural coliform mastitis in cows. Infect. Immun. 13(2), 533-542.

Harmon, R.J., Schanbacher, F.L., Ferguson, L.C., and Smith, K.L. 1975. Concentration of lactoferrin in milk of normal lactating cows and changes occurring during mastitis. Am. J. Vet. Res. 36(7), 1001-1007.

Huang, P., Lu, C., Li, J., Xu, J., Liu, Z., Wang, Q., Wang, Z., Huo, J., Li, H., Teng, Y., and Cai, Y. 2015. Mutations in HSP70-2 gene change the susceptibility to clinical mastitis in Chinese Holstein. Gene 559(1), 62-72. doi: 10.1016/j.gene.2015.01.015.

Huang, Y.Q., Morimoto, K., Hosoda, K., Yoshimura, Y., and Isobe, N. 2012. Differential immunolocalization between lingual antimicrobial peptide and lactoferrin in mammary gland of dairy cows. Vet. Immunol. Immunopathol. 145(1-2), 499-504. doi:

10.1016/j.vetimm.2011.10.017.

Hurley, W.L., and Rejman, J.J. 1993. Bovine lactoferrin in involuting mammary tissue. Cell Biol. Int. 17(3), 283-289. doi: 10.1006/cbir.1993.1064.

Hyvönen, P., Käyhkö, S., Taponen, S., von Wright, A., and Pyörälä, S. 2009. Effect of bovine lactoferrin on the internalization of coagulase-negative staphylococci into bovine mammary epithelial cells under in-vitro conditions. J. Dairy Res. 76(2), 144-151. doi: 10.1017/S0022029908003774.

Ishido, T., Nishiyama, T., Kim, W.-S., Kumura, H., Shimazaki, K., Motoshima, H., and Kawai, K. 2011. Continuous supply of $\mathrm{OSCN}^{-}$ions by lactoperoxidase system developed from lactose as the primary substrate and its antibacterial activities. Milchwissenschaft 66(1), 76-80. CAB Abstract AN:20113068273.

Ishikawa, H., Serizawa, A., Ahiko, K., Asai, Y., and Seike, N. 1992. Changes in the chemical composition of colostrum from Japanese black cows. Anim. Sci. Technol. 63(11), $1153-1156$.

Itagaki, M., and Tanaka, S. Immunostimulation of bovine lactoferrin (bLf) on cattle infected with mastitis and its application to clinical mastitis cases. In XIIth International Conference on Lactoferrin, Structure, Function and Applications (Abstract), 2-6 November 2015. Nagoya, Japan.

Jenssen, H., and Hancock, R.E.W. 2009. Antimicrobial properties of lactoferrin. Biochimie 91(1), 19-29. doi: 10.1016/j.biochi.2008.05.015.

Kai, K., Komine, Y., Komine, K., Asai, K., Kuroishi, T., Kozutsumi, T., Itagaki, M., Ohta, M., and Kumagai, K. 2002a. Effects of bovine lactoferrin by the intramammary infusion in cows with Staphylococcal mastitis during the early non-lactating period. J. Vet. Med. Sci. 
64(10), 873-878. doi: 10.1292/jvms64.873.

Kai, K., Komine, K., Komine, Y., Kuroishi, T., Kozutsumi, T., Kobayashi, J., Ohta, M., Kitamura, H., and Kumagai, K. 2002b. Lactoferrin stimulates A Staphylococcus aureus killing activity of bovine phagocytes in the mammary gland. Microbiol. Immunol. 46(3), 187-194. doi: 10.1111/j.1348-0421.2002.tb02685.x.

Kawai, K., Hagiwara, S., Anri, A., and Nagahata, H. 1999. Lactoferrin concentration in milk of bovine clinical mastitis. Vet. Res. Commun. 23(7), 391-398.

Kawai, K., Korematsu, K., Akiyama, K., Okita, M., Yoshimura, Y., and Isobe, N. 2014. Dynamics of lingual antimicrobial peptide, lactoferrin concentrations and lactoperoxidase activity in the milk of cows treated for clinical mastitis. Anim. Sci. J. 86(2), 153-158. doi: 10.1111/asj.12269.

Kawai, K., Nagahata, H., Lee, N.Y., Anri, A., and Shimazaki, K. 2003. Effect of infusing lactoferrin hydrolysate into bovine mammary glands with subclinical mastitis. Vet. Res. Commun. 27(7), 539-548. doi: 10.1023/A:1026039522286.

Kawai, K., Shimazaki, K., Higuchi, H., and Nagahata, H. 2007. Antibacterial activity of bovine lactoferrin hydrolysate against mastitis pathogens and its effect on superoxide production of bovine neutrophils. Zoonoses Public Health 54(3-4), 160-164. doi: 10.1111/j.1863-2378.2007.01031.x.

Komine, Y., Komine, K.-I., Kai, K., Itagaki, M., Kuroishi, T., Aso, H., Obara, Y., and Kumagai, K. 2006. Effect of combination therapy with lactoferrin and antibiotics against staphylococcal mastitis on drying cows. J. Vet. Med. Sci. 68(3), 205-211. doi: 10.1292/jvms.68.205.

Krömker, V., and Friedrich, J. 2009. Teat canal closure in non-lactating heifers and its association with udder health in the consecutive lactation. Vet. Microbiol. 134(1-2), 100-105. doi: 10.1016/j.vetmic.2008.09.002.

Kushibiki, S. 2011. Tumor necrosis factor- $\alpha$-induced inflammatory responses in cattle. Anim. Sci. J. 82(4), 504-511. doi: 10.1111/j.1740-0929.2011.00931.x.

Kushibiki, S., Shingu, H., Kawasaki, R., Komatsu, T., Itoh, F., Watanabe, A., Touno, E., Oshibe, A., Katoh, K., Obara, Y., and Hodate, K. 2008. Effect of bovine lactoferrin feeding on lipopolysaccharide-induced metabolic and hormonal disturbances in preruminant calves. Anim. Sci. J. 79(3), 375-381. doi: 10.1111/j.1740-0929.2008.00540.x.

Kushibiki, S., Shingu, H., Komatsu, T., Itoh, F., Moriya, N., Touno, E., Oshibe, A., and Hodate, K. 2009. Influence of orally administered bovine lactoferrin on lipid metabolism in lipopolysaccharide-injected preruminant calves. Anim. Sci. J. 80(3), 258-264. doi: 10.1111/j.1740-0929.2009.00642.x.

Kutila, T., Pyörälä, S., Kaartinen, L., Vahtola, K., Myllykoski, L., and Saloniemi, H. 2002. Disposition kinetics of lactoferrin in milk after intramammary administration. J. Vet. Pharmacol. Ther. 25(2), 129-133. doi: 10.1046/j.1365-2885.2002.00391.x.

Kutila, T., Suojala, L., Lehtolainen, T., Saloniemi, H., Kaartinen, L., Tähti, M., Seppälä, K., 
and Pyörälä, S. 2004. The efficacy of bovine lactoferrin in the treatment of cows with experimentally induced Escherichia coli mastitis. J. Vet. Pharmacol. Ther. 27(4), 197-202. doi: 10.1111/j.1365-2885.2004.00581.x.

Lacasse, P., Lauzon, K., Diarra, M.S., and Petitclerc, D. 2008. Utilization of lactoferrin to fight antibiotic-resistant mammary gland pathogens. J. Anim. Sci. 86(13 Suppl), 66-71. doi: 10.2527/jas.2007-0216.

Latorre, D., Berlutti, F., Valenti, P., Gessani, S., and Puddu, P. 2012. LF immunomodulatory strategies: mastering bacterial endotoxin. Biochem. Cell Biol. 90(3), 269-278. doi: 10.1139/o11-059.

Legrand, D. 2012. Lactoferrin, a key molecule in immune and inflammatory processes. Biochem. Cell Biol. 90(3), 252-268. doi: 10.1139/o11-056.

Levy, O. 1996. Antibiotic proteins of polymorphonuclear leukocytes. Eur. J. Haematol. 56(5), 263-277. doi: 10.1111/j.1600-0609.1996.tb00714.x.

Machnicki, M., Zimecki, M., and Zagulski, T. 1993. Lactoferrin regulates the release of tumour necrosis factor alpha and interleukin 6 in vivo. Int. J. Exp. Pathol. 74(5), 433-439.

Mattsby-Baltzer, I., Roseanu, A., Motas, C., Elverfors, J., Engberg, I., and Hanson, L.A. 1996. Lactoferrin or a fragment thereof inhibits the endotoxin-induced interleukin- 6 response in human monocytic cells. Pediatr. Res. 40(2), 257-262. doi: 10.1203/00006450-199608000-00011.

McDougall, S., Parker, K.I., Heuer, C., and Compton, C.W.R. 2009. A review of prevention and control of heifer mastitis via non-antibiotic strategies. Vet. Microbiol. 134(1-2), 177-185. doi: 10.1016/j.vetmic.2008.09.026.

Meade, K.G., Cormican, P., Narciandi, F., Lloyd, A., and O'Farrelly, C. 2014. Bovine $\beta$-defensin gene family: opportunities to improve animal health? Physiol. Genomics 46(1), 17-28. doi: 10.1152/physiolgenomics.00085.2013.

Middleton, J.R., Saeman, A., Fox, L.K., Lombard, J., Hogan, J.S., and Smith, K.L. 2014. The National Mastitis Council: A Global Organization for Mastitis Control and Milk Quality, 50 Years and Beyond. J. Mammary Gland Biol. Neoplasia 19(3), 241-251. doi: 10.1007/s10911-014-9328-6.

Morimoto, K., Shimizu, M., Kurose, T., Nakatani, K., Akita, S., Shinozuka, Y., and Isobe, N. 2011. Efficacy of enterotoxigenic Escherichia coli vaccine for bovine clinical mastitis. J. Dairy Res. 78(2), 149-153. doi: 10.1017/S0022029911000069.

Murata, M., Wakabayashi, H., Yamauchi, K., Toida, T., and Iwatsuki, K. Influence of lipopolysaccharides on the antimicrobial activity of lactoferrin against Escherichia coli. In IXth International Conference on Lactoferrin (Abstract). 18-22 October 2009. Beijing, China.

Orsi, N. 2004. The antimicrobial activity of lactoferrin: current status and perspectives.

Biometals 17(3), 189-196. doi: 10.1023/B:BIOM.0000027691.86757.e2.

Petitclerc, D., Lauzon, K., Cochu, A., Ster, C., Diarra, M.S., and Lacasse, P. 2007. Efficacy of 
a lactoferrin-penicillin combination to treat $\beta$-lactam-resistant Staphylococcus aureus mastitis. J. Dairy Sci. 90(6), 2778-2787. doi: 0.3168/jds.2006-598.

Prgomet, C., Prenner, M.L., Schwarz, F.J., and Pfaffl, M.W. 2007. Effect of lactoferrin on selected immune system parameters and the gastrointestinal morphology in growing calves. J. Anim. Physiol. Anim. Nutr. (Berl). 91(3-4), 109-119. doi: 10.1111/j.1439-0396.2006.00649.x.

Puddu, P., Latorre, D., Valenti, P., and Gessani, S. 2010. Immunoregulatory role of lactoferrin-lipopolysaccharide interactions. Biometals 23(3), 387-397. doi: 10.1007/s10534-010-9307-3.

Pyörälä, S. 2003. Indicators of inflammation in the diagnosis of mastitis. Vet. Res. 34(5), 565-578. doi: 10.1051/vetres:2003026.

Reiter, B., and Oram, J.D. 1967. Bacterial inhibitors in milk and other biological fluids. Nature 216(5113), 328-330. doi: 10.1038/216328a0.

Sallmann, F.R., Baveye-Descamps, S., Pattus, F., Salmon, V., Branza, N., Spik, G., and Legrand, D. 1999. Porins OmpC and PhoE of Escherichia coli as specific cell-surface targets of human lactoferrin. Binding characteristics and biological effects. J. Biol. Chem. 274(23), 16107-16114. doi: 10.1074/jbc.274.23.16107.

Sanchez, M.S., and Watts, J.L. 1999. Enhancement of the activity of novobiocin against Escherichia coli by lactoferrin. J. Dairy Sci. 82(3), 494-499. doi: 10.3168/jds.S0022-0302(99)75259-8.

Schalm, O.W., Carroll, E.J., and Jain, N.C. 1971. Bovine mastitis. Philadelphia, USA: Lea \& Febiger.

Schmitz, S., Pfaffl, M.W., Meyer, H.H.D., and Bruckmaier, R.M. 2004. Short-term changes of mRNA expression of various inflammatory factors and milk proteins in mammary tissue during LPS-induced mastitis. Domest. Anim. Endocrinol. 26(2), 111-126. doi: 10.1016/j.domaniend.2003.09.003.

Sherman, M.P. 2010. New concepts of microbial translocation in the neonatal intestine: mechanisms and prevention. Clin. Perinatol. 37(3), 565-79. doi: 10.1016/j.clp.2010.05.006.

Shinoda, I., Takase, M., Fukuwatari, Y., Shimamura, S., Köller, M., and König, W. 1996. Effects of Lactoferrin and Lactoferricin on the Release of Interleukin 8 from Human Polymorphonuclear Leukocytes. Biosci. Biotechnol. Biochem. 60(3), 521-523. doi: $10.1271 / \mathrm{bbb} .60 .521$

Singh, P.K., Parsek, M.R., Greenberg, E.P., and Welsh, M.J. 2002. A component of innate immunity prevents bacterial biofilm development. Nature 417(6888), 552-555. doi: 10.1038/417552a.

Smith, K.L., and Schanbacher, F.L. 1977. Lactoferrin as a factor of resistance to infection of the bovine mammary gland. J. Am. Vet. Med. Assoc. 170(10 Pt 2), 1224-1227.

Suzuki, T., Nonaka, M., Kiyosawa, I., and Ogasa, K. 1977. Lactoferrin contents in bovine 
colostrum and milk. Eiyou to Shokuryo 30(5), 317-322 (in Japanese).

Suzuki, T., Yamauchi, K., Kawase, K., Tomita, M., Kiyosawa, I., and Okonogi, S. 1989.

Collaborative bacteriostatic activity of bovine lactoferrin with lysozyme against Escherichia coli O111. Agric. Biol. Chem. 53(6), 1705-1706.

Swanson, K., Gorodetsky, S., Good, L., Davis, S., Musgrave, D., Stelwagen, K., Farr, V., and Molenaar, A. 2004. Expression of a $\beta$-defensin mRNA, lingual antimicrobial peptide, in bovine mammary epithelial tissue is induced by mastitis. Infect. Immun. 72(12), 7311-7314. doi:10.1128/IAI.72.12.7311-7314.2004.

Targowski, S.P. 1983. Role of immune factors in protection of mammary gland. J. Dairy Sci. 66(8), 1781-1789. doi: 10.3168/jds.S0022-0302(83)82006-2.

Thompson-Crispi, K., Atalla, H., Miglior, F., and Mallard, B.A. 2014. Bovine mastitis:

Frontiers in immunogenetics. Front. Immunol. 5, 493. doi:10.3389/fimmu.2014.00493.

Available from https://www.ncbi.nlm.nih.gov/pmc/articles/PMC4188034/?tool=pmcentrez [accessed 19 January 2017].

Tsuji, S., Hirata, Y., Mukai, F., and Ohtagaki, S. 1990. Comparison of lactoferrin content in colostrum between different cattle breeds. J. Dairy Sci. 73(1), 125-128. doi: 10.3168/jds.S0022-0302(90)78654-7.

Wall, R.J., Powell, A.M., Paape, M.J., Kerr, D.E., Bannerman, D.D., Pursel, V.G., Wells, K.D., Talbot, N., and Hawk, H.W. 2005. Genetically enhanced cows resist intramammary Staphylococcus aureus infection. Nature Biotechnol. 23(4), 445-451. doi: 10.1038/nbt1078.

Watanabe, T., Nagura, H., Watanabe, K., and Brown, W.R. 1984. The binding of human milk lactoferrin to immunoglobulin A. FEBS Lett. 168(2), 203-207. doi:

10.1016/0014-5793(84)80246-X.

World Health Organization, 2015. WHO | Global action plan on antimicrobial resistance

[WWW Document]. Available from

http://www.who.int/drugresistance/global_action_plan/en/ [accessed 19 January 2017].

Yen, C.-C., Shen, C.-J., Hsu, W.-H., Chang, Y.-H., Lin, H.-T., Chen, H.-L., and Chen, C.-M. 2011. Lactoferrin: an iron-binding antimicrobial protein against Escherichia coli infection. Biometals 24(4), 585-94. doi: 10.1007/s10534-011-9423-8. 
Table 1. Main mastitis-causing microorganisms reported*

Brucella melitensis, Corynebacterium bovis, Enterobacter aerogenes, Escherichia coli, Klebsiella pneumoniae, Klebsiella oxytoca, Mycoplasma, Pasteurella spp., Proteus spp., Prototheca zopfii, Prototheca wickerhamii, Pseudomonas aeruginosa, Staphylococcus aureus, Staphylococcus epidermidis, Streptococcus agalactiae, Streptococcus uberis, Trueperella pyogenes, Yeast-like fungi

* Bradley, 2002; Kawai et al., 2007; De Vliegher et al., 2012; 
Table 2. Bacteria isolated from mastitis milk show various sensitivity against lactoferrin, lactoferrin-hydrolyzate by pepsin and lactoperoxidase

\begin{tabular}{|c|c|c|c|}
\hline bacteria & lactoferrin* & $\begin{array}{c}\text { lactoferrin } \\
\text { hydrolyzate* }\end{array}$ & lactoperoxidase ${ }^{* *}$ \\
\hline Streptococcus uberis & + & + & + \\
\hline Klebsiella pneumoniae & + & + & - \\
\hline Staphylococcus aureus & + & - & + \\
\hline $\begin{array}{l}\text { Staphylococcus xylosus }{ }^{\#} \text {, Enterococcus } \\
\text { faecium, Enterococcus raffinosus }\end{array}$ & - & + & - \\
\hline $\begin{array}{l}\text { Staphylococcus epidermidis }{ }^{\#}, \\
\text { Staphylococcus haemolyticus } \\
\text {, } \\
\text { Staphylococcus simulans }{ }^{\#} \text {, Streptococcus } \\
\text { dysgalactiae, Streptococcus equinus }\end{array}$ & - & + & + \\
\hline Escherichia coli, Enterococcus faecalis & - & - & - \\
\hline Prototheca zophii & + & + & nd \\
\hline $\begin{array}{l}\text { Staphylococcus capitis }{ }^{\#} \text {, Staphylococcus } \\
\text { equorum }^{\#} \text {, Staphylococcus schleiferi }\end{array}$ & 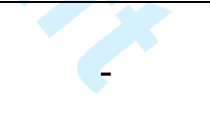 & + & nd \\
\hline
\end{tabular}

* Kawai et al. (2007), ** Ishido et al. (2011)

+ , sensitive; -, resistant; nd, not determined

Note that the sensitivities are strain dependent.

\# Bacteria marked are coagulase-negative staphylococci (CNS) and this classification has been used based on diagnostic procedures (Becker et al., 2014). They are major pathogens of bovine mastitis (Hyvönen et al., 2009). 
Table 3. Effects of intramammary infusion of lactoferrin against bovine mastitis.

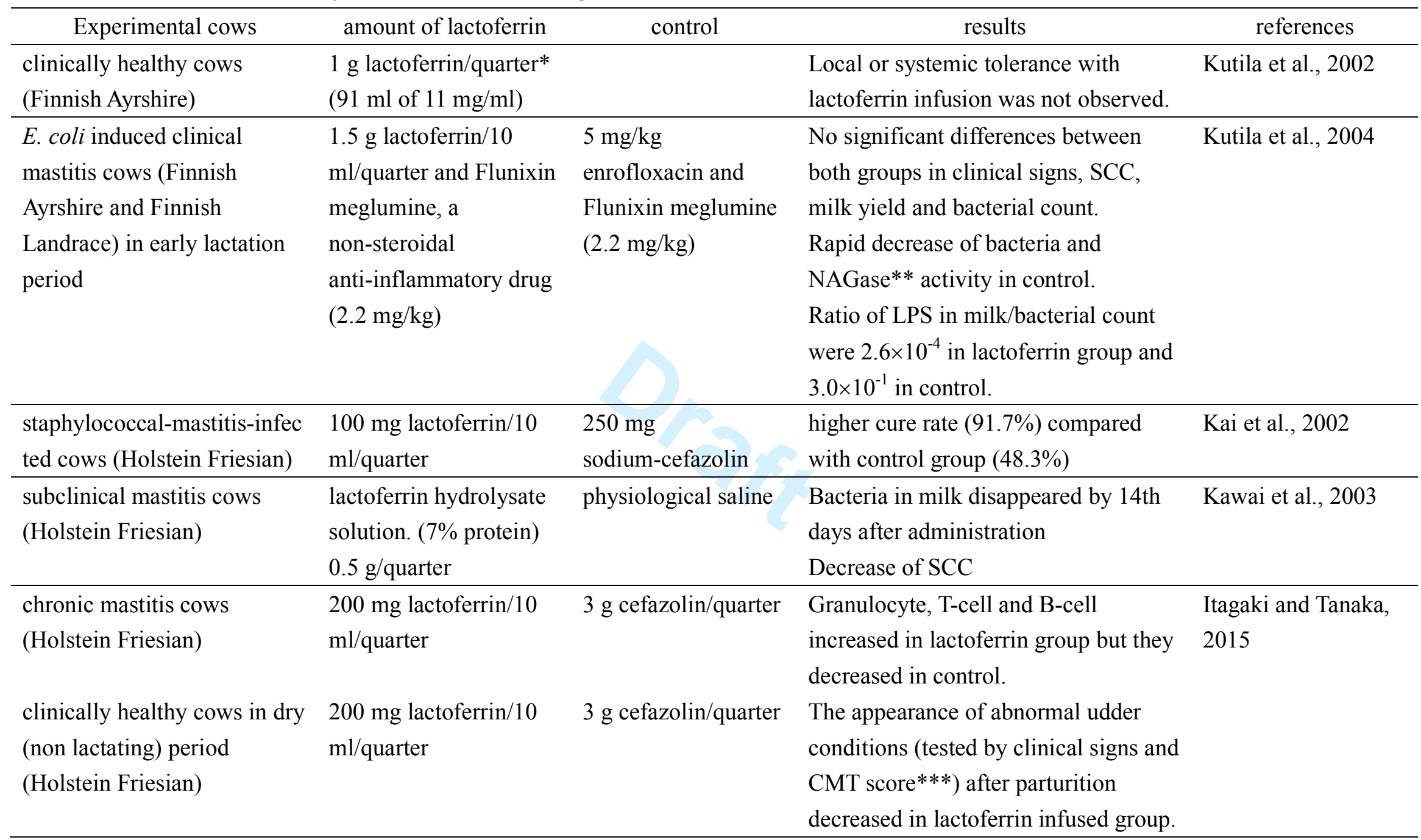

* Cow has four udders and quarter means an udder.

** NAGase, N-acetyl- $\beta$-glucosaminidase, used as an indicator of inflammation (Pyörälä, 2003).

*** CMT score, California Mastitis Test score, a indicator of inflammation and milk conditions (Pyörälä, 2003). 
Table 4. Some examples about combination use of lactoferrin with antibiotics

\begin{tabular}{llll}
\hline $\begin{array}{l}\text { antibiotics } \\
\text { combined }\end{array}$ & $\begin{array}{l}\text { experimental conditions } \\
\text { and target pathogens }\end{array}$ & \multicolumn{1}{c}{ results } & \multicolumn{1}{c}{ references } \\
\hline novobiocin & in vitro (E. coli) & $\begin{array}{l}\text { increased antibacterial } \\
\text { activity }\end{array}$ & Sanchez and Watts, 1999 \\
& & $\begin{array}{l}\text { increased antibacterial } \\
\text { activity }\end{array}$ & Diarra et al., 2002, 2003 \\
\hline penicillin G & in vitro (S. aureus) & higher cure rate & Petitclerc et al., 2007 \\
& & $\begin{array}{l}\text { (33.3\%) compared } \\
\text { penicillin G }\end{array}$ & late-lactating cows \\
& mastitis induced by & alone (12.5\%) & \\
& $\beta$-lactam-resistant $S$. & high cure rate of $81 \%$ & Komine et al., 2006 \\
& aureus & & \\
\hline cefazolin & drying cows & & \\
& clinical mastitis infected & & \\
& by $S$. aureus & & \\
\hline
\end{tabular}

